\title{
A High-Resolution Hydrographic Contrast Between the East China Sea and the Japan Sea Based on Foraminiferal Isotopic Records for the Late Holocene
}

\author{
HUI-LING LIN ${ }^{1}$, SHIH-MING WU ${ }^{1}$ and CHUNG-HO WANG ${ }^{2}$ \\ (Manuscript received 26 September 1995, in final form 9 April 1996)
}

\begin{abstract}
High-resolution foraminiferal isotopic records obtained from cores from the East China Sea and Japan Sea reveal a pattern of contrasting hydrographies for the last 6000 years. The first core, retrieved from the upper continental slope of the East China Sea, was analyzed for $\delta^{18} O$ and $\delta^{13} \mathbf{C}$ in both Neogloboquadrina dutertrei (planktonic) and Uvigerina spp. (benthic) foraminifera and, hence, provides a record of paleoceanographic change through time. The relatively reduced amplitude of the planktonic $\delta^{18} \mathrm{O}$ signal relative to the benthic samples suggests some modification resulting from changes in the prevailing Kuroshio Current. A progressive depletion in both the $\delta^{18} \mathrm{O}$ and $\delta^{13} \mathrm{C}$ records of $N$. dutertrei over the last 2000 years suggests a warmer, more humid climate around the East China Sea. Isotopic records of the second core collected from the Japan Sea show a comparable temporal resolution to those from the East China Sea, but they exhibit larger amplitudes presumably due to the more restricted hydrographic setting and greater sensitivity to environmental changes in that area. In addition to the temperature differences revealed by oxygen isotopes, the $N$. dutertrei $\delta^{13} \mathbf{C}$ records for these two cores also provide clues as to the evolution of the Kuroshio Current during the late Holocene.
\end{abstract}

(Key words: Foraminiferal isotopic records, East China Sea, Japan Sea)

\section{INTRODUCTION}

The Kuroshio Current plays a major role in modulating the climate of the Northwestem Pacific through the meridional transport of watermass, heat and freshwater. This current is largely modified both quantitatively and qualitatively by its interaction with shelf waters as it passes through eastern Taiwan and flows into the East China Sea (Nitani, 1972; Ichikawa and

\footnotetext{
1 Institute of Marine Geology, National Sun Yat-Sen University, Kaohsiung, Taiwan, R.O.C.

2 Institute of Earth Sciences, Academia Sinica, P. O. Box 1-55, Nankang, Taiwan, R.O.C.
} 
Beardsley, 1993). The Tsushima Warm Current is one of the Kuroshio branches which enters the Japan Sea via the Tsushima Strait (Toba et al., 1982). Situated at the boundary between the open ocean and the Eurasian continent, the Kuroshio Current is inevitably affected by the prevailing monsoon system. Thus, paleoceanographic records from this area offer the potential of providing insight into both the evolution of the regional climate and hydrographic conditions in the western Pacific. Here a new high-resolution isotopic record with $\mathrm{AMS}^{14} \mathrm{C}$ age control from the East China Sea that provides a record of paleoceanographic change for the last 6000 years is presented. In addition, a comparable resolution record from the Japan Sea offers a the opportunity to contrast the hydrographic settings between these two sites through time. Although many studies regarding the paleoceanographic change in the Japan Sea have been carried out (e.g., Oba et al., 1991; Keigwin and Gorbarenko, 1992), even the ODP Leg 127 and 128 in 1989 were both devoted to the evolution of the Japan Sea; also the time-scales in those studies were much larger than one millennium.

\section{MATERIALS AND METHODS}

Core samples for this study were obtained during the ROC-Russia Joint Expedition, $R / V$ Akademik Aleksandr Vinogradov Cruise V23/KM92 from July 10 to August 5, 1992 (Chen and Bychkov, 1992). The $525 \mathrm{~cm}$ long piston core V23/KM92-E25a (E25a) was retrieved from the East China Sea $\left(29^{\circ} 07.6^{\prime} \mathrm{N}, 127^{\circ} 48.2^{\prime} \mathrm{E}\right)$ at a water depth of $1090 \mathrm{~m}$ (Figure 1). The $540 \mathrm{~cm}$ long piston core V23/KM92-J3 (J3) was collected from the southem Japan Sea $\left(35^{\circ} 53.8^{\prime} \mathrm{N}, 130^{\circ} 15.0^{\prime} \mathrm{E}\right)$ at a water depth of $1400 \mathrm{~m}$. A detailed carbonate stratigraphy of core J3 has been published by Gorbarenko et al. (1995). However, only the results from the

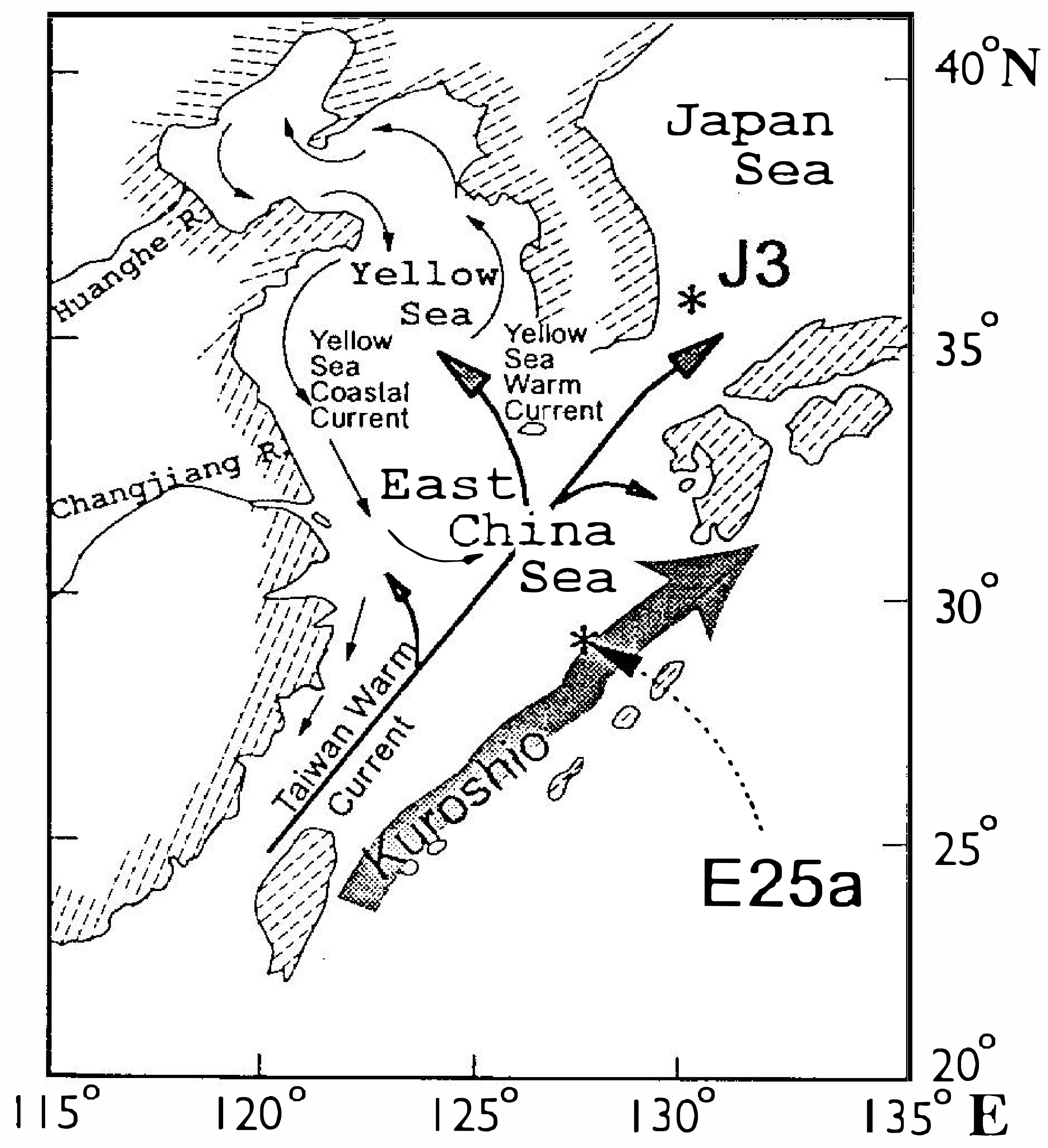

Fig. 1. Map of the study area showing the location of cores E25a and J3. Schematic of regional circulation is indicated based on Beardsley et al. (1985). 
top $3.5 \mathrm{~m}$ in core $\mathrm{J} 3$, covering the last 6000 years, are discussed here. Because the original sampling strategy was designed for organic geochemistry analysis, samples were taken that integrate 5, and sometimes even $10 \mathrm{~cm}$ intervals, for each downcore sample onboard ship. That is, all the data reported here represent average values covering 5 to $10 \mathrm{~cm}$ intervals rather than the more discrete sample intervals usually taken. Although it is likely that such broad sampling has smoothed original signals, the extreme high sedimentation rates at both locations still provide a high resolution view of events over the past 6000 years.

Specimens of deep-dwelling planktonic foraminifer Neogloboquadrina dutertrei for both stable isotope analysis and AMS ${ }^{14} \mathrm{C}$ dating were picked from the dry coarse fraction after wet sieving through a $125 \mu \mathrm{m}$ size sieve. No further sizing was taken for isotope work afterwards due to low abundance of foraminifera. Foraminifera were then ultrasonically cleaned in AR-grade methanol to remove adhering particles. Further cleaning for organic matter was done by soaking in a solution of $5 \% \mathrm{NaClO}$ for 12 hours. Isotope analyses were made on a SIRA-10 Mass Spectrometer in the Geochemistry Laboratory of the Institute of Earth Sciences, Academia Sinica, Taipei. Specimens of the benthic foraminifer Uvigerina $s p p$. were picked from the East China Sea core E25a for isotopic analysis and were processed under similar procedures. All isotopic data are reported in Appendix I as parts per thousand $(\% o)$ using the conventional notation relative to the Pee Dee Belemnite (PDB). The analytical precision expressed as $1 \sigma$ for NBS-18, NBS-19 and the laboratory standards are better than $0.06 \%$. The average difference of replicate foraminiferal analyses is about $0.19 \%$ for $\delta^{18} \mathrm{O}$ and $0.11^{o} \%_{o o}$ for $\delta^{13} \mathrm{C}$. The AMS ${ }^{14} \mathrm{C}$ dating of $N$. dutertrei samples was completed at the Institute of Geological and Nuclear Sciences in New Zealand. $\triangle^{14} \mathrm{C}$ and per cent modern are as defined by Stuiver and Polasch (1977).

Sediment texture, especially the particle size distribution in deep sea sediments, is an important parameter in understanding the sedimentary environments and previous transport processes. The mean size of the non-cohesive silt fraction $(10-63 \mu \mathrm{m})$ has been used here as an indicator of relative current strength since bottom currents size-sort coarse silt during events of resuspension and ensuing deposition (e.g., Haskell et al., 1991; McCave et al., 1995). In this study, particle size analyses for bulk sediments from core E25a were performed on a laser diffraction grain size analyzer (Coulter LS100). The downcore size distribution provides information regarding changes in current intensity around this area.

\section{RESULTS AND DISCUSSION}

\subsection{AMS ${ }^{14} \mathrm{C}$ Dates and Sedimentation Rates}

The $\mathrm{AMS}^{14} \mathrm{C}$ dates generated from monospecific samples of $N$. dutertrei for both cores J3 and E25a are listed in Table 1. Age models were developed on the basis of linear interpolation between adjacent radiocarbon dates. The calculated sedimentation rates in the Japan Sea core J3 are between 50 and $100 \mathrm{~cm} / \mathrm{kyr}$ for the last 6000 years. The sedimentation rates in core E25a are much higher, ranging between 75 and $140 \mathrm{~cm} / \mathrm{kyr}$. Even when ${ }^{14} \mathrm{C}$ ages are converted into calendar ages prior to the calculation based on the program CALIB 3.03C (Stuiver and Reimer, 1993), the sedimentation rates are still over $100 \mathrm{~cm} / \mathrm{kyr}$ for most sections of core E25a. For comparison with other referenced data, all ages in this paper are expressed in radiocarbon years. According to the age model, the age for the base of core E25a is estimated to be around 5500 radiocarbon years old. Each sample $(5 \mathrm{~cm}$ interval samples) in the top $100 \mathrm{~cm}$ of core E25a represents an average of 70 years of deposition, 
Table 1. AMS ${ }^{14} \mathrm{C}$ dates generated from monospecific samples of $N$. dutertrei. The last column lists the reservoir-corrected age obtained by 400 years (Bard, 1988).

\begin{tabular}{||l|l|c|c||}
\hline Depth $(\mathrm{cm})$ & $\Delta^{14} \mathrm{C}(\%)$ & ${ }^{14} \mathrm{C}$ age $(\mathrm{yr})$ & Corr. age $(\mathrm{yr})$ \\
\hline $\mathrm{J} 3 ; 55-60$ & $-212.2 \pm 6.5$ & $1873 \pm 66$ & 1470 \\
\hline $\mathrm{J} 3 ; 210-220$ & $-395.9 \pm 5.4$ & $4006 \pm 72$ & 3600 \\
\hline$J 3 ; 280-290$ & $-445.8 \pm 4.5$ & $4698 \pm 66$ & 4300 \\
\hline$E 25 a ; 5-10$ & $-76.7 \pm 7.9$ & $598 \pm 68$ & 200 \\
\hline E25a; $210-220$ & $-343.2 \pm 6.1$ & $3334 \pm 75$ & 2930 \\
\hline E25a; $270-280$ & $-380.7 \pm 5.3$ & $3806 \pm 69$ & 3400 \\
\hline E25a; $340-350$ & $-423.0 \pm 5.9$ & $4374 \pm 82$ & 3970 \\
\hline E25a; $520-525$ & $-530.5 \pm 5.7$ & $6031 \pm 98$ & 5630 \\
\hline
\end{tabular}

while data points $(10 \mathrm{~cm}$ interval samples) from below $100 \mathrm{~cm}$ downcore represent around 70 90 years. In the Japan Sea core J3, data points from the upper $200 \mathrm{~cm}$ represent about 70 years, but expand to around 100 to 150 years as the sampling intervals increased to 10 $\mathrm{cm}$ below $200 \mathrm{~cm}$ downcore and as the sedimentation rates decreased.

\subsection{Particle Size Distribution}

Results of particle size analyses for core E25a are summarized in Figure 2, which the geometric mean of particle size distributions are shown in the upper part of Figure 5. Even though most of the particle size distributions fall in the range of silt, there is a general fining upward trend with a clear transition zone between two size-domains. The size distributions below $490 \mathrm{~cm}$ (curve D in Figure 2 before 5400 years B.P. in age), i.e., grain size in the bottom part of E25a, are relatively coarse compared to that of the upper sections with a mode of around $35 \mu \mathrm{m}$. The size distributions in the interval of 400 and $490 \mathrm{~cm}(4600 \sim 5400$ years B.P.) illustrated by curves $\mathrm{C}$ and B, show bimodal patterns. These bimodal distributions, however, are distinctive with two different modes. The mode is about $35 \mu \mathrm{m}$ in curve $\mathrm{C}$ (for core interval between $440-490 \mathrm{~cm}$; 4900-5400 years B.P.), but it shifts toward around $12 \mu \mathrm{m}$ in curve B (for $400-440 \mathrm{~cm}$; $4600-4900$ years B.P.). Curve A represents the general size distribution pattern for the core section above $400 \mathrm{~cm}$, peaking in the category of fine silt (7-15.6 $\mu \mathrm{m}$ according to grade scale). The geometric mean of particle size is generally around $11 \mu \mathrm{m}$ except for the base section (before 5000 years B.P., Figure 5). A distinctive peak up to more than $20 \mu \mathrm{m}$ is recorded around 4000 years B.P..

\subsection{The Oxygen Isotope Records}

Even though the size fraction of planktonic foraminifera was prohibited due to the low abundance, the $\delta^{18} \mathrm{O}$ values generated from core $\mathrm{J} 3$ are very similar to the same core reported by Gorbarenko and his associates (1995). It seems, to some extent, that the potential influence caused by size fraction is not very discemible, especially under the conditions of a broad sampling interval $(5$ to $10 \mathrm{~cm}$ vs. traditional $1 \mathrm{~cm}$ ). Therefore, the following discussion is based on the assumption that such restrction are vaild.

\subsubsection{Planktonic Records}

The $\delta^{18} \mathrm{O}$ results derived from the $N$. dutertrei from cores E25a and J3 are plotted versus estimated age in the upper panel of Figure 3 with different vertical scales at the left ( -2 to $\left.0^{\circ} \%_{o o}\right)$ and right $\left(0\right.$ to $\left.2^{\circ} \%_{o o}\right)$, respectively. When studied in detail no obvious covariation 


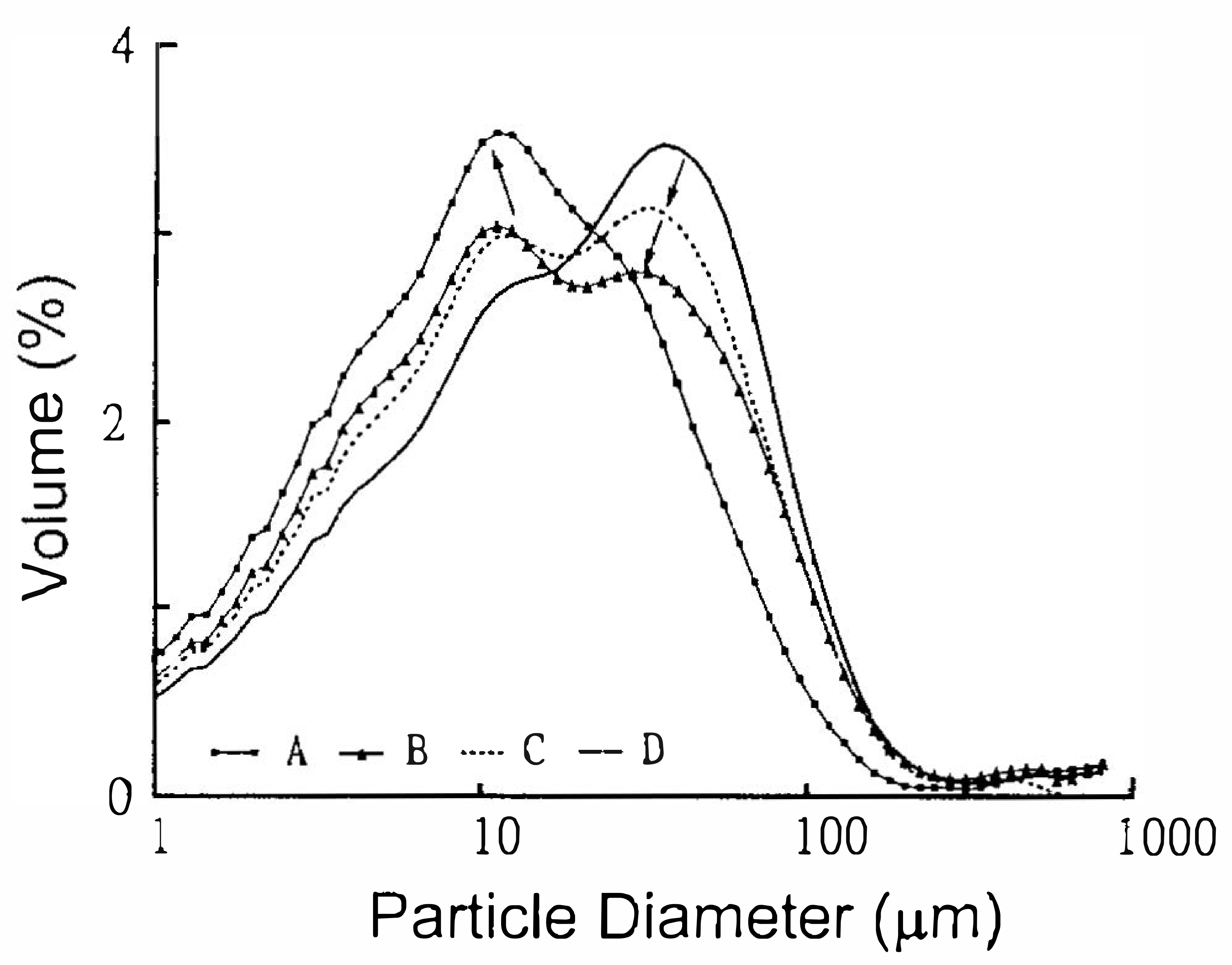

Fig. 2. Particle size distribution (mode) of core E25a. The vertical axis shows the volume percentage, while the horizontal axis shows the particle diameter in logarithmic scale. Curves A to D stand for different sections in core. See text for further detail.
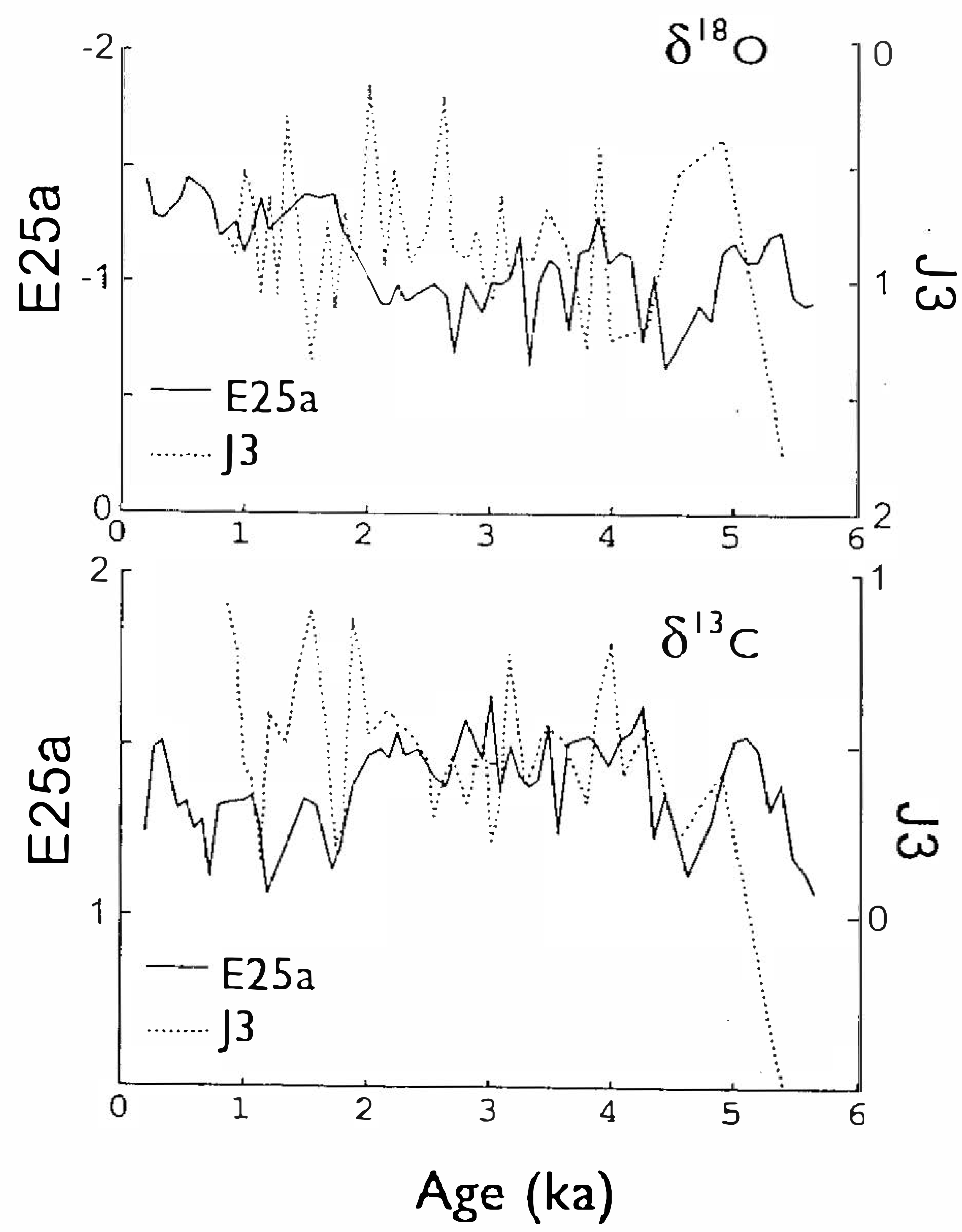

Fig. 3. Time series of the $\delta^{18} \mathrm{O}$ and $\delta^{13} \mathrm{C}$ of $N$. dutertrei from cores E25a and J3. The scales show a $2^{\circ} \%_{o o}$ difference on the right and left of the two cores. Both $\delta^{18} \mathrm{O}$ and $\delta^{13} \mathrm{C}$ are calibrated to PDB. 
between these two records is apparent. Over the last 2000 years, variations in $\delta^{18} \mathrm{O}$ in E25a show a progressively depleting trend compared to the general pattern for the same interval in the $\mathrm{J} 3$ record.

It is clear that the $2^{\circ} \%_{o o}$ offset in the $\delta^{18} \mathrm{O}$ compositions of $N$. dutertrei between these two cores was primarily caused by the different hydrological settings of these two sites. Currently, the difference in the sea surface temperatures between these two sites is about $7^{\circ} \mathrm{C}\left(29^{\circ} \mathrm{C}\right.$ at E25a relative to $21.6^{\circ} \mathrm{C}$ at $\mathrm{J} 3$ for surface; $21.5^{\circ} \mathrm{C}$ at E25a relative to 15.5 at $75 \mathrm{~m}$ ) based on measurements at the time of the cruise (Figure 4; Chen and Bychkov, 1992). The temperature effects alone, therefore, account for about $1.7 \%$ of the difference in the average $\delta^{18} \mathrm{O}$ composition (Craig, 1965). In general, the $\delta^{18} \mathrm{O}$ fluctuation range for $\mathrm{J} 3$ (about $1.6^{\circ} \%_{o o}$ ) is two times greater than that for E25a $\left(0.75^{\circ} \%\right.$, Figure 3$)$. The different hydrographic settings of these two localities may have contributed to the difference in the amplitudes of the $\delta^{18} \mathrm{O}$ signal, since the semi-enclosed Japan Sea is expected to be more sensitive to environmental changes, which would tend to amplify its signals.

\subsubsection{Benthic Record}

The oxygen isotopic record for Uvigerina spp. from core E25a is shown in Figure 5. Most of the benthic $\delta^{18} \mathrm{O}$ values in this record are around $2.5^{\circ} \%$ except for a few ${ }^{18} \mathrm{O}$ depleted spikes. Surprisingly, the total fluctuation range for the benthic $\delta^{18} \mathrm{O}$ signal $\left(1.6^{\circ} \%\right.$ oo is larger than that of the planktonic signal $\left(0.8^{\circ} \%\right.$; Figure 5). The larger amplitude of the benthic $\delta^{18} \mathrm{O}$ record than the planktonic one is not likely to be due to species-dependent effects. Instead, it seems more likely that the larger fluctuations of the benthic $\delta^{18} \mathrm{O}$ values resulted from variations in the ambient water since the $\delta^{18} \mathrm{O}$ composition of Uvigerina spp. is very close to the ${ }^{18} \mathrm{O}$ equilibrium values (Graham et al., 1981). In particular, there is an abrupt and brief positive-shift in the interval between 4000 and 5000 years B.P., followed by a sharp and pronounced $\mathrm{O}^{18}$-depleted spike around 4000 years B.P.. A step-wise $\delta^{18} \mathrm{O}$ enriched trend then brings the $\delta^{18} \mathrm{O}$ values from $\sim 1.3^{\circ} \%_{o o}$ to $\sim 2.6 \%$ (Figure 5). After 3000 years B.P., the oxygen isotopic compositions of Uvigerina spp. are relatively stable at around $2.5^{\circ} \%_{o o}$, but are slightly depleted $(0.2-0.3 \%$ oo $)$ in the last 2000 years, which is similar to the trend in the $N$. dutertrei records.

\subsection{The Carbon Isotope Records}

\subsubsection{Planktonic Records}

The lower panel in Figure 3 shows the $\delta^{13} \mathrm{C}$ records from $N$. dutertrei for cores E25a and J3. In contrast to the $2^{o} \%$ offset between the two sites for the $\delta^{18} \mathrm{O}$ records in the upper panel, there is only a $1^{\circ} \%_{o o}$ difference in the $\delta^{13} \mathrm{C}$ between the two cores. The $\delta^{13} \mathrm{C}$ values of $N$. dutertrei from core E25a fluctuate between 1.1 and $1.6 \%$, while those from $\mathrm{J} 3$ are between -0.1 and $0.9^{\circ} \%_{o o}$ with most values heavier than $0.2^{\circ} \%_{o o}$. Of special interest is the fact that these two $\delta^{13} \mathrm{C}$ curves are generally more coherent over the period of 1000 to 5000 years B.P.. Over the last 2000 years, the depletion shift in ${ }^{13} \mathrm{C}$ in core E25a relative to the Japan Sea core J3 in the Japan Sea seems to match the general ${ }^{18} \mathrm{O}$ depletion trend except that it has a smaller amplitude (Figure 3).

In surface water, $\delta^{13} \mathrm{C}$ is controlled by the relative importance of biological and thermodynamically controlled processes. Carbon isotopes are fractionated by photosynthesis during the production of organic matter and to a lesser extent, during the formation of $\mathrm{CaCO}_{3}$. The 
preferential incorporation of ${ }^{12} \mathrm{C}$ into the organic matter leaves the surface seawater enriched in $\delta^{13} \mathrm{C}$. $N$. dutertrei is generally thought to have a $\delta^{13} \mathrm{C}$ composition in equilibrium with the ambient $\delta^{13} \mathrm{C}$ of $\Sigma \mathrm{CO}_{2}$ (Fairbanks et al., 1982; Sautter and Thunell, 1991). As a dweller at a depth of around $100 \mathrm{~m}, N$. dutertrei lacks the endosymbionts that appear to contribute to the "vital effects" observed in many planktonic species (Helmleben et al., 1989). Therefore, the $\delta^{13} \mathrm{C}$ compositions of $N$. dutertrei from this study are considered to be reliable indicators of the $\delta^{13} \mathrm{C}$ of the near-surface water. To estimate the $\delta^{13} \mathrm{C}$ of the total dissolved inorganic carbon of ambient seawater $\left(\Sigma \mathrm{CO}_{2}\right)$, the equation of Grossman (1982), modified from Epstein et al. (1953) was employed:

$$
\text { equilibrium calcite } \delta^{13} C=\left(\delta^{13} C \text { of }\left(\Sigma \mathrm{CO}_{2}\right)+\left(10.51-\left(2980 /\left(t_{w}+273\right)\right)\right)\right. \text {, }
$$

where $t_{w}$ is the temperature in degrees Celsius of ambient seawater. The average $\delta^{13} \mathrm{C}$ values of $N$. dutertrei $(1.38 \%$ for $\mathrm{E} 25 \mathrm{a}$ and $0.52 \%$ for $\mathrm{J} 3)$ and temperatures at the depth of $75 \mathrm{~m}$ (Chen and Bychkov, 1992) were applied and the estimated $\Sigma \mathrm{CO}_{2} \delta^{13} \mathrm{C}$ values of $0.99 \%$ and $0.34 \%$ for cores E25a and J3, respectively were obtained. The difference in the $\Sigma \mathrm{CO}_{2} \delta^{13} \mathrm{C}$ compositions between $\mathrm{E} 25 \mathrm{a}$ and $\mathrm{J} 3$ is $0.65^{\circ} \%$, which accounts for about $75 \%$ of the difference in average foraminiferal $\delta^{13} \mathrm{C}$ compositions $\left(1.38-0.52=0.86^{\circ} \%_{o o}\right.$; $0.65 / 0.86 \approx 75 \%$ ).

As previously discussed, the differences in the hydrographic setting of these two localities probably play an important role in the observed differences in the foraminiferal isotopic compositions. Nutrient concentrations (especially $\mathrm{PO}_{4}$ ), which reflect the balance between nutrient supply and surface productivity, are closely related to the $\delta^{13} \mathrm{C}$ of $\Sigma \mathrm{CO}_{2}$. The inverse correlation between the $\delta^{13} \mathrm{C}$ and $\mathrm{PO}_{4}$ is $0.93^{\circ}$ oo per $\mu \mathrm{M} / \mathrm{kg}$ according the calculations of Broecker and Peng (1982). In this case, the phosphate concentrations in the East China Sea are generally more depleted than those of the Japan Sea by about $0.2 \sim 0.3 \mu \mathrm{M}$ for the upper $100 \mathrm{~m}$ in the water column (Figure 4; Chen and Bychkov, 1992), which in turn could
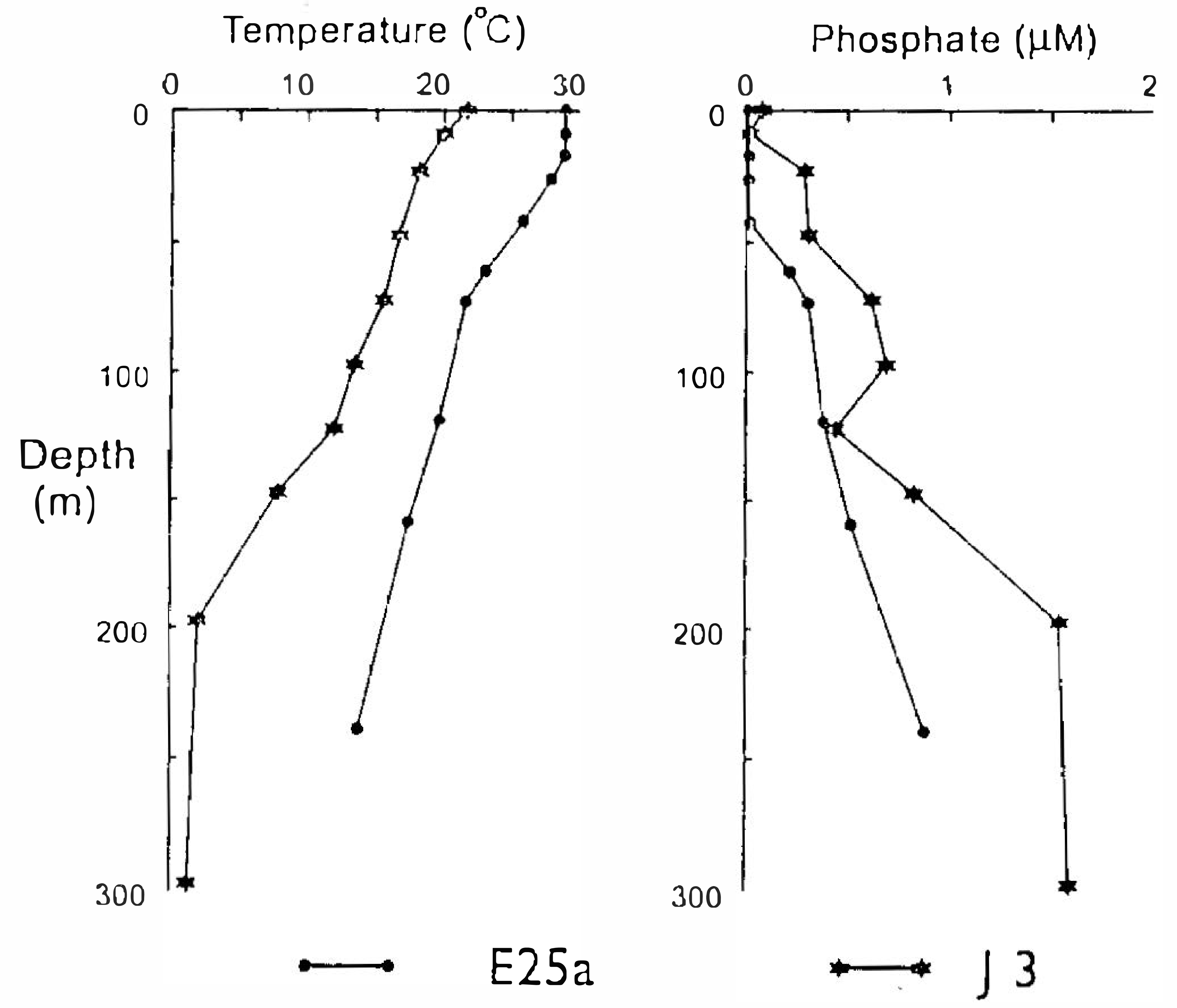

Fig. 4. Temperature and phosphate profiles in the East China Sea (E25a) and Japan Sea (J3). 
result in a $0.19 \sim 0.28^{\circ} \%_{o o}$ change in $\delta^{13} \mathrm{C}$. This nutrient-induced shift, therefore, seems to be adequate in accounting for the missing one quarter difference between the estimated of the $\Sigma \mathrm{CO}_{2} \delta^{13} \mathrm{C}$ and foraminiferal $\delta^{13} \mathrm{C}$ discussed above.

\subsubsection{Benthic Record}

The lower part of Figure 5 shows the $\delta^{13} \mathrm{C}$ record of Uvigerina spp. for core E25a. Unlike the $\delta^{18} \mathrm{O}$ records, the range of fluctuations in the benthic $\delta^{13} \mathrm{C}$ record is more or less similar to that in the planktonic one. Most of the $\delta^{13} \mathrm{C}$ values are around $-1.2 \pm 0.2^{\circ} \%$, except for a few brief $\mathrm{C}^{13}$-depleted intervals. Among these ${ }^{13} \mathrm{C}$-depleted intervals, there is a distinct negative $\delta^{13} \mathrm{C}$ excursion around 4000 years B.P. which corresponds to the conspicuous $\delta^{18} \mathrm{O}$ depletion in the benthic $\delta^{18} \mathrm{O}$ record (Figure 5). The combination of both depletion in $\delta^{18} \mathrm{O}$ and $\delta^{13} \mathrm{C}$, together with the sudden increase in the geometric mean of particle size as indicated at the top of Figure 5, strongly suggests an increase in the influence of freshwater. The mechanism responsible for this freshwater imprint, however, does not go undebated since the $\delta^{18} \mathrm{O}$ depletion is not shown in the planktonic record.

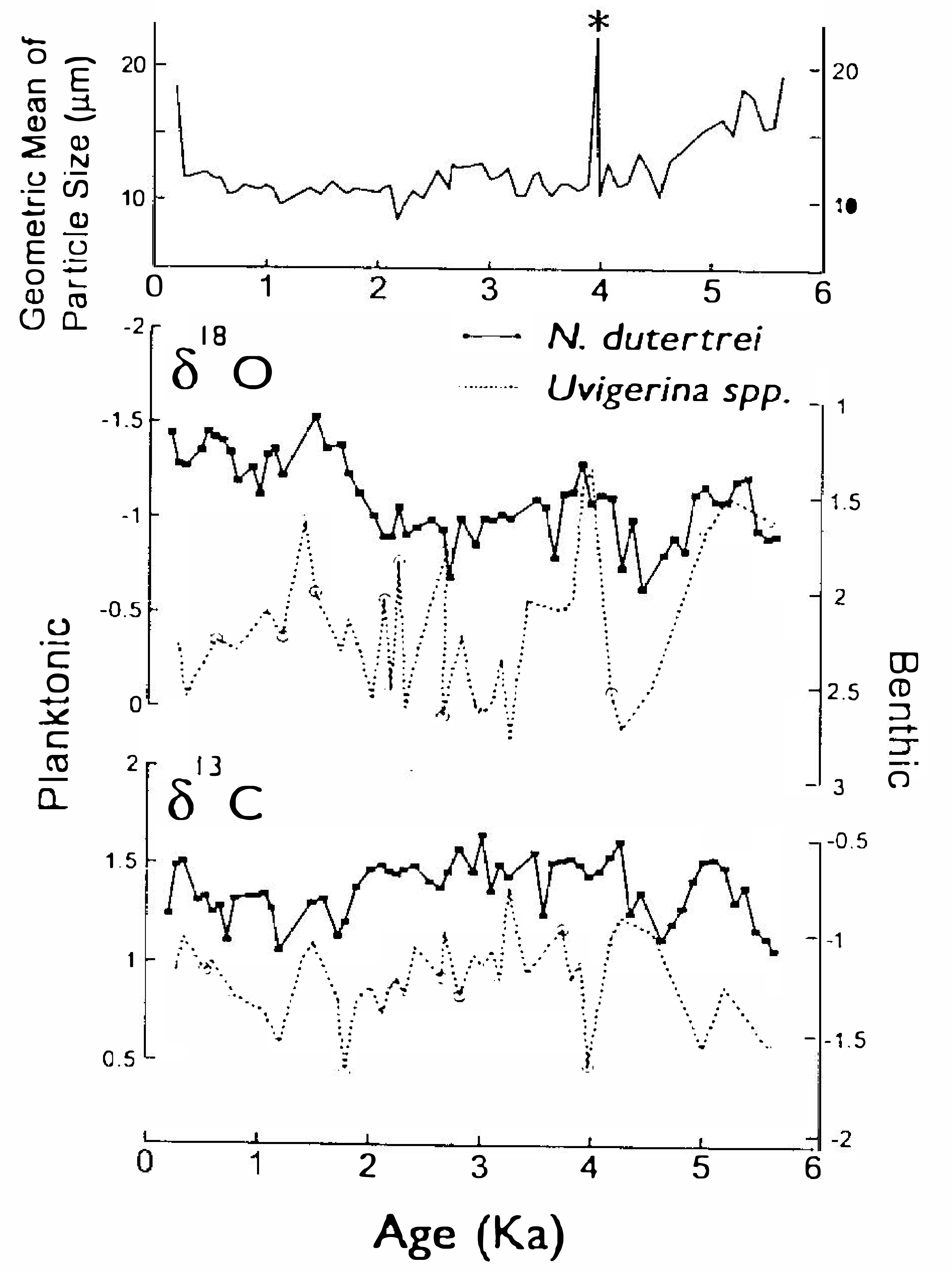

Fig. 5. Time series of $\delta^{18} \mathrm{O}$ and $\delta^{13} \mathrm{C}$ of $N$. dutertrei (planktonic) and Uvigerina spp. (benthic) from core E25a with the geometric mean of particle size distribution across the top. Different scales are labeled at right and left for $N$. dutertrei and Uvigerina spp., respectively. Both $\delta^{18} \mathrm{O}$ and $\delta^{13} \mathrm{C}$ are calibrated to PDB. The * sign superimposed on the particle size distribution curve marks the abrupt increase in particle diameter around 4000 years B.P.. 


\section{THE PALEOCEANOGRAPHY OF THE EAST CHINA SEA FOR THE LAST 6000 YEARS}

Stratigraphic variations in foraminiferal $\delta^{18} \mathrm{O}$ over the Pleistocene largely represent the waxing and waning of continental ice sheets and hence reflect both the climate and sea level from a long-term perspective. In comparison with changes in the ocean-water isotopic composition, the temperature effect is usually a subordinate contribution to the values of $\delta^{18} \mathrm{O}$ recorded in foraminiferal shells. For example, a $1.2 \%$ difference in the $\delta^{18} \mathrm{O}$ composition of inorganic precipitated carbonate between the last glacial and the Holocene is generally expected (e.g., Fairbanks, 1989) and according to Craig (1965) would account for about a $6^{\circ} \mathrm{C}$ temperature change. In this study, however, excursions in both the planktonic and benthic $\delta^{18} \mathrm{O}$ records are interpreted as local temperature and/or salinity effects since the size of the polar ice sheets and, hence, the $\delta^{18} \mathrm{O}$ composition of the global mean ocean water have been relatively constant for the last 6000 years. It is true that the "spiky" pattern of $\delta^{18} \mathrm{O}$ in the benthic record (Figure 5) is not conceivable in an oceanographic perspective. Turbidites could be easily invoked to interpret such abrupt changes. But with five AMS ${ }^{14} \mathrm{C}$ dates from core E25a (Table 1), the continuity of these isotopic records seems plausible.

In this paper, the $\delta^{18} \mathrm{O}$ records of $N$. dutertrei and Uvigerina spp. provide information on the upper water column and bottom water in the East China Sea through time, respectively. The generally similar patterns of the two curves in Figure 5 suggest that the mechanisms controlling the isotopic composition of the watermass, and hence the hydrographic setting in this area, are rather uniform within the water column. Because the prevailing current in this region is the Kuroshio, the strong western boundary current, it is likely that any variability in the Kuroshio is responsible for the recorded $\delta^{18} \mathrm{O}$ signals. However, it is unusual that fluctuations in the amplitude of the benthic record are significantly larger than those in the planktonic one (Figure 5), particularly during the period between 4000 and 5000 years B.P.. Since the property of watermasses in the deep ocean is generally more stable than that of the surface, it is conceivable that the $\delta^{18} \mathrm{O}$ composition in the bottom water signaled a more direct influence of the variation source than in the upper water column which is regulated by the dominant Kuroshio water. The spike-like negative deviations in the benthic $\delta^{18} \mathrm{O}$ record, however, probably were derived from the pulsive input of watermasses from the continental side of the Kuroshio, e.g., the Taiwan Current Warm Water and the Yellow Sea Cold Water (Beardsley et al., 1985; Gong and Liu, 1994), if the water had been cold enough to sink. Over the last 2000 years, a progressive depletion of $\delta^{18} \mathrm{O}$ in both $N$. dutertrei and Uvigerina $s p p$. is observed. Unlike the earlier interval, the amplitude of the planktonic signal is larger than the benthic signal, suggesting a more influential impact in the upper water column. It is probable that the $\delta^{18} \mathrm{O}$ depletion in the planktonic record resulted from warmer temperatures and/or less saline seawater due to increased net precipitation.

The present geographic distribution of $\delta^{13} \mathrm{C}$ in the deep ocean is closely related to the oxygen and nutrient contents of the various water masses and is strongly dependent on thermohaline circulation patterns (Kroopnick, 1985). On the other hand, the distribution of $\delta^{13} \mathrm{C}$ in surface waters is more complex and depends on the magnitude of the $\mathrm{CO}_{2}$ exchange with the atmosphere, mixing with the thermocline waters and isotopic fractionation during photosynthesis. Therefore, the correlation between planktonic and benthic $\delta^{13} \mathrm{C}$ records, with proper species selection, can be regarded as an indicator of the presence of some active water exchange between surface and deep water (e.g., Duplessy et al., 1988; Sarnthein et al., 1988). However, a number of studies have shown that the $\delta^{13} \mathrm{C}$ composition of the genus 
Uvigerina does not faithfully reflect that of the bottom water $\Sigma \mathrm{CO}_{2}$ because of its infaunal microhabitat (Graham et al., 1981; Vincent et al., 1981; Duplessy and Shackleton, 1985; Oppo et al., 1990); they also reveal that isotopic composition is related to the accumulation rates of organic carbon (Zahn et al., 1986).

The lower part of Figure 5 shows the time series of $\delta^{13} \mathrm{C}$ for $N$. dutertrei and Uvigerina spp.. There is a general agreement between the $\delta^{13} \mathrm{C}$ trends of planktonic and benthic foraminifera except in the case of few peculiar intervals. The relative spiky and depleted pattern of benthic $\delta^{13} \mathrm{C}$ might have resulted from the lateral transport from the upper continental slope. It is difficult to imagine the scenario of freshwater input as suggested by $\delta^{18} \mathrm{O}$ records (Figure 5). Yet the intermittent down slope transport of particles that moves contemporary depositions could be an alternative mechanism for those ${ }^{18} \mathrm{O}$ - and ${ }^{13} \mathrm{C}$-depletion intervals. The lateral transport of particulate organic carbon across the shelf break to the deep sea off northeastem Taiwan was documented by Liu et al. (1995). Based on repeated surveys, Liu and his associates (1995) concluded that the oligotrophic water of the Kuroshio Current was not likely a sufficient source of the patchy particulate organic carbon observed in the underlying water. Instead, the relatively high particulate organic carbon concentration in shelf water they found could have been the major source of the organic carbon-enriched sediments on the slope. Furthermore, based on a suite of 58 surface sediment samples from the continental margin of the East China Sea (Sheu et al., 1995), relatively light values of $\delta^{13} \mathrm{C}$ in carbonates are mostly found in water depths of less than $90 \mathrm{~m}$. The difference in the $\delta^{13} \mathrm{C}$ compositions in surface sediments between shallow and deep sites could be over $2^{o} \%_{o o}$. Therefore, the scattering but relatively ${ }^{18} \mathrm{O}$ - and ${ }^{13} \mathrm{C}$-depleted signals of benthic foraminifera might have been resulted from the concurrent rework of particles (sediments) from shallower depths.

In summary, a comparison of the planktonic isotopic records from cores E25a and J3 reveals offsets that reflect the hydrographic contrast between the East China Sea and the Japan Sea. The general difference in the $\delta^{18} \mathrm{O}$ in these areas can be fully explained by the temperature effect. On the other hand, differences in nutrient concentrations are invoked to explain that part of the $\delta^{13} \mathrm{C}$ offset between cores E25a and J3 that can't be explained by temperature alone. The apparent covariant trend of the $\delta^{13} \mathrm{C}$ curves in Figure 3 seems to indicate that the $\delta^{13} \mathrm{C}$ pulses observed in the Japan Sea are linked to those of the East China Sea by changes in the Kuroshio Current. The watermass in the upper water column is largely modulated by the Kuroshio Current as reflected by the reduced amplitude of the planktonic record relative to the benthic one. The significant freshwater flux, or rather an increase in the lateral transport in this area before 5000 years B.P. and around 4000 years B.P. are shown by the synchronous shifts of $\delta^{18} \mathrm{O}$ and $\delta^{13} \mathrm{C}$ and the relatively coarser particles (Figure 5). The indication of warmer and/or more humid climate over the last 2000 years is indicated by the progressive $\delta^{18} \mathrm{O}$ depletion in $N$. dutertrei.

Acknowledgements The authors are grateful to Profs. D.-D. Sheu and B.-D. Yuan at the Institute of Marine Geology, National Sun Yat-Sen University and Prof. M.-P. Chen at the Institute of Oceanography, National Taiwan University for making this study possible. Ms. S.-F. Wu, P.-S. Tsai, C.-S. Lin and L.-W. Wang are thanked for their assistance in isotope analyses. The manuscript benefited from the critical review of an anonymous reviewer and Prof. L.-C. Peterson at the -University of Miami. This research was supported by grant NSC83-0209-M110-006. 


\section{REFERENCES}

Beardsley, R. C., Limeburner, R., Yu, H., and G. A. Cannon, 1985: Discharge of the Changiiang (Yangtze River) into the East China Sea. Cont. Shelf Res., 4, 57-76.

Broecker, W. S., and T.-H. Peng, 1982: Tracers in the Sea, Eldigio Press, Palisades, New York, p.690.

Chen, M. -P., and A. Bychkov, 1992: ROC-Russia Marine Science Collaboration Project, KEEP-MASS Initial Data Report on the $R / V$ Akademik Aleksandr Vinogradov Cruise V23/KM92, NSC, Taipei, 440pp.

Craig, H., 1965, The measurement of oxygen isotope paleotemperatures: In: E. Tongiorgi (Ed.), Stable Isotopes in Oceanographic Studies and Paleotemperatures, Consiglio Nazionale Delle Ricerche, Laboratorio Di Geologia Nucleare, Pisa, 9-130.

Duplessy, J. C. and N. J. Shackleton, 1985, Response of global deep-water circulation to Earth's climatic change 135,000-107,000 years ago. Nature, 316, 50-507.

Duplessy, J. C., N. J. Shackleton, R. G. Fairbanks, L. Labeyrie, D. Oppo, and N. Kallel, 1988: Deep water source variations during the last climatic variations and their impact on the global deep water circulation. Paleoceanography, 3, 343-360.

Epstein, S., R. Buchsbaum, H. A. Lowenstam, and H. C. Urey, 1953: Revised carbonatewater isotopic temperature scale. Geol. Soc. Am. Bull., 64, 1315-1326.

Fairbanks, R. G., 1989: A 17,000 year glacial-eustatic sea level record: Influence of glacial melting rates on the Younger Dryas event and deep-ocean circulation. Nature, 342, 637-642.

Gong, G.-C., and K.-K. Liu, 1994: Summertime hydrography and nutrient dynamics in the East China Sea: International Symposium on Global Fluxes of Carbon and Its Substance in Coastal Sea-Ocean-Atmospheric System, Hokkaido, Japan, Nov. 14-17, 1994.

Gorbarenko, S. A., S. G. Pliss, J. R. Southon, M. Kashgarian, N. B. Verkhovskaya, and A. S. Kundyshev, 1995: Detailed carbonate Stratigraphy of the Japan Sea sediments during last Glaciation-Holocene. TAO, 6, 103-113.

Graham, D. W., B. H. Corliss, M. L. Bender, and L. D. Keigwin, 1981: Carbon and oxygen isotopic disequilibria of recent deep-sea benthic foraminifera. Mar. Micropaleonto., 6, 483-479.

Grossman, E. L., 1982: Stable Isotopes in Live Benthic Foraminifera from the Southern California Borderland. Ph. D. dissertation, University of Southern California, 164pp.

Haskell, B. J., T. C. Johnson, and W. J. Showers, 1991: Fluctuations in deep western North Atlantic circulation on the Blake Outer Ridge during the Last Deglaciation. Paleoceanography, 6, 21-31.

Hemleben, C., M. Spindler, and O. R. Anderson, 1989: Modern Planktonic Foraminifera, Springer-Verlag, New York, 363pp.

Ichikawa, H., and R. C. Beardsley, 1993: Temporal and spatial variability of volume transport of the Kuroshio in the East China Sea. Deep-Sea Res., 40, 583-605.

Keigwin, L. D., and S. A. Gorbarenko, 1992: Sea level, surface salinity of the Japan Sea, and the Younger Dryas event in the northwestern Pacific Oecan. Quat. Res., 37, 346-360. 
Kroopnick, P., 1985: The distribution of $\delta^{13} \mathrm{C}$ of $\Sigma \mathrm{CO}_{2}$ in the world oceans. Deep-Sea Res., 32, 57-84.

Liu, K.-K., Z-Y. Lai, G.-C. Gong, and F.-K. Shiah, 1995: Distribution of particulate organic matter in the southem East China Sea: Implications in production and transport. TAO, 6, 27-45.

McCave, I. N., B. Manighetti, and N. A. S. Beveridge, 1995: Circulation in the glacial North Atlantic inferred from grain-size measurements. Nature, 374, 149-151.

Nitani, T., 1972: Beginning of the Kuroshio. In: H. Stommel and K. Yoshide (Eds.), Kuroshio, University of Washington Press, 129-156.

Oba, T., M. Katon, H. Kitazato, I. Koizumi, A. Omura, T. Sakai, and T. Takayama, 1991: Paleoenvironmental changes in the Japan Sea during the last 85,000 years. Paleoceanography, 6, 499-518.

Oppo, D. W., R. G. Fairbanks, A. L. Gordon, and N. J. Shackleton, 1990: Late Pleistocene southern ocean $\delta^{13} \mathrm{C}$ variability. Paleoceanography, 5, 43-54.

Samthein, M., K. Winn, J. C. Duplessy, and M. R. Fontugne, 1988: Global variations of surface ocean productivity in low and mid latitudes. Influence on $\mathrm{CO}_{2}$ reservoirs of the deep ocean and atmosphere during the last 21,000 years. Paleoceanography, 3, 361-399.

Sautter, L. R., and R. C. Thunell, 1991: Seasonal variability in $\delta^{18} \mathrm{O}$ and $\delta^{13} \mathrm{C}$ of planktonic foraminifera from an upwelling environment: Sediment trap results from the San Pedro Basin, Southem Califomia Bight. Paleoceanography, 6, 307-334.

Sheu, D. D., W.-C. Jou, M.-J. Chen, W.-Y. Lee, and S. Lin, 1995: Variations of calcium carbon, organic carbon and their compositions in surface sediments of the East China Sea. TAO, 6, 115-128.

Stuiver, M., and H. Polach, 1977: Discussion: Reporting of ${ }^{14} \mathrm{C}$ data. Radiocarbon, 19, 355-363.

Stuiver, M., and P. J. Reimer, 1993: Extended ${ }^{14} \mathrm{C}$ data base and revised Calib $3.0{ }^{14} \mathrm{C}$ age calibration program. Radiocarbon, 35, 215-230.

Toba, Y., K. Tomizaqa, Y. Kurasawa, and K. Hanawa, 1982: Seasonal and year-to year variability of the Tsushima-Tsugaru Warm Current system with its possible cause. La Mer, 20, 41-51.

Vincent, E., J. S. Killingley, and W, H. Berger, 1981: Stable isotope composition of benthic foraminifera from the equatorial Pacific. Nature, 289, 639-643.

Zahn, R., K. Winn, and M. Sarnthein, 1986: Benthic foraminiferal $\delta^{13} \mathrm{C}$ and accumulation rates of organic carbon: Uvigerina peregrina and Cibicidoides wuellerstorfi. Paleoceanography, 1, 27-42. 
Appendix I. Isotopic data for $N$. dutertrei and Uvigerina spp. from cores E25a and J3. Both $\delta^{18} \mathrm{O}$ and $\delta^{13} \mathrm{C}$ are calibrated to the conventional standard PDB. Age estimates for each sample are based on the AMS ${ }^{14} \mathrm{C}$ age model for each core. 2

\begin{tabular}{|c|c|c|c|c|c|c|c|c|c|}
\hline \multicolumn{6}{|c|}{ Core E25a } & \multirow{2}{*}{\multicolumn{4}{|c|}{$\begin{array}{c}\text { Core J3 } \\
\text { N. dutentrei }\end{array}$}} \\
\hline \multicolumn{4}{|c|}{ N. dutertrei } & \multicolumn{2}{|c|}{ Uvigerina spp. } & & & & \\
\hline $\operatorname{Depth}(\mathrm{cm})$ & Age $(y r)$ & $\delta^{110} 09_{00}$ & $\delta^{13} \mathrm{C} \Phi_{\infty}$ & $\delta^{10} \mathrm{O} 900$ & $b^{13} \mathrm{C} \% 0$ & Depth(cm) & Age (yr) & $\delta^{18} \mathrm{O} \%_{0}$ & $\delta^{13} \mathrm{C} 9_{\infty}$ \\
\hline 7.5 & 200 & -1.44 & 1.24 & & & 12.5 & 861 & 0.81 & 0.91 \\
\hline 12.5 & 266 & -1.28 & 1.49 & 2.29 & -1.20 & 17.5 & 929 & 0.88 & 0.79 \\
\hline 17.5 & 332 & -1.27 & 1.51 & 2.57 & -1.03 & 22.5 & 997 & 0.51 & 0.44 \\
\hline 27.5 & 463 & -1.35 & 1.31 & & & 27.5 & 1064 & 0.66 & 0.39 \\
\hline 32.5 & 529 & -1.45 & 1.33 & 2.93 & -1.19 & 32.5 & 1132 & 1.06 & 0.15 \\
\hline 37.5 & 595 & -1.42 & 1.25 & 2.27 & -1.15 & 37.5 & 1200 & 0.63 & 0.59 \\
\hline 42.5 & 660 & -1.40 & 1.28 & & & 42.5 & 1267 & 1.06 & 0.54 \\
\hline 47.5 & 726 & -1.34 & 1.11 & & & 47.5 & 1335 & 0.28 & 0.50 \\
\hline 52.5 & 792 & -1.19 & 1.32 & 2.32 & -1.32 & 52.5 & 1402 & 0.62 & 0.67 \\
\hline 62.5 & 924 & -1.26 & 1.33 & & & 57.5 & 1470 & 1.90 & 0.73 \\
\hline 67.5 & 989 & -1.12 & 1.33 & & & 62.5 & 1538 & 1.34 & 0.90 \\
\hline 72.5 & 1055 & -1.33 & 1.35 & 2.11 & -1.40 & 67.5 & 1605 & 1.45 & 1.02 \\
\hline 77.5 & 1121 & -1.36 & 1.27 & & & 72.5 & 1673 & 0.74 & 0.51 \\
\hline 82.5 & 1187 & -1.22 & 1.06 & 2.25 & -1.56 & 77.5 & 1740 & 1.12 & 0.20 \\
\hline 97.5 & 1384 & & & 1.64 & -1.15 & 82.5 & 1808 & 0.70 & 0.27 \\
\hline 105.0 & 1483 & -1.53 & 1.30 & 2.02 & -1.05 & 87.5 & 1876 & 0.92 & 0.87 \\
\hline 112.5 & 1581 & -1.36 & 1.32 & & & 92.5 & 1943 & 0.83 & 0.74 \\
\hline 122.5 & 1713 & -1.38 & 1.13 & 2.33 & -1.34 & 97.5 & 2011 & 0.14 & 0.53 \\
\hline 127.5 & 1779 & -1.23 & 1.20 & 2.16 & -1.69 & 102.5 & 2079 & 1.58 & 0.22 \\
\hline 135.0 & 1877 & -1.13 & 1.38 & 2.31 & -1.35 & 107.5 & 2146 & 0.93 & 0.60 \\
\hline 145.0 & 2009 & -1.01 & 1.47 & 2.58 & -1.27 & 112.5 & 2214 & 0.51 & 0.58 \\
\hline 152.5 & 2108 & -0.90 & 1.49 & 2.06 & -1.41 & 117.5 & 2281 & 1.44 & 0.58 \\
\hline 157.5 & $2: 73$ & -0.90 & 1.46 & 2.53 & -1.28 & 122.5 & 2349 & 0.92 & 0.53 \\
\hline 162.5 & 2239 & -1.06 & 1.45 & 1.85 & -1.23 & 132.5 & 2484 & 0.78 & 0.46 \\
\hline 167.5 & 2305 & -0.91 & 1.47 & 2.62 & -1.32 & 137.5 & 2552 & 0.48 & 0.28 \\
\hline 175.0 & 2404 & -0.95 & 1.49 & 2.33 & -1.07 & 142.5 & 2620 & 0.19 & 0.40 \\
\hline 185.0 & 2535 & -0.99 & 1.41 & & & 147.5 & 2687 & 0.85 & 0.47 \\
\hline 192.5 & 2634 & -0.94 & 1.38 & 2.66 & -1.22 & 157.5 & 2822 & 0.90 & 0.32 \\
\hline 195.0 & 2667 & & & 1.79 & -0.99 & 162.5 & 2890 & 0.77 & 0.46 \\
\hline 197.5 & 2700 & -0.69 & 1.46 & & & 167.5 & 2958 & 0.98 & 0.52 \\
\hline 205.0 & 2798 & -1.00 & 1.58 & 2.24 & -1.31 & 172.5 & 3025 & 1.08 & 0.21 \\
\hline
\end{tabular}


(Appendix I. Continued.)

\begin{tabular}{|c|c|c|c|c|c|c|c|c|c|}
\hline Depth $(\mathrm{cm})$ & Age (yr) & $\delta^{18} \mathrm{O} \%_{00}$ & $\delta^{13} \mathrm{C} x_{0}$ & $\delta^{18} \mathrm{O} \%$ & $\delta^{\prime \prime} \mathrm{C} 9_{00}$ & $\operatorname{Depch}(\mathrm{cm})$ & Age $(y r)$ & $\delta^{18} \mathrm{O} \mathscr{x}_{0}$ & $\delta^{13} \mathrm{C} \%$ \\
\hline 215.0 & 2930 & .0 .86 & 1.46 & 2.62 & -1.11 & 177.5 & 3093 & 0.62 & 0.32 \\
\hline 225.0 & 3008 & -1.00 & 1.65 & 2.64 & -1.17 & 182.5 & 3160 & 0.97 & 0.77 \\
\hline 235.0 & 3087 & -0.99 & 1.36 & 2.59 & -1.08 & 187.5 & 3228 & 0.90 & 0.60 \\
\hline 245.0 & 3165 & -1.02 & 1.50 & 2.36 & -1.23 & 192.5 & 3296 & 0.90 & 0.38 \\
\hline 255.0 & 3243 & -1.00 & 1.44 & 2.79 & -0.77 & 197.5 & 3363 & 0.90 & 0.44 \\
\hline 275.0 & 3400 & & & 2.05 & -1.20 & 205.0 & 3465 & 0.68 & 0.56 \\
\hline 285.0 & 3481 & -1.10 & 1.56 & & & 215.0 & 3600 & 0.80 & 0.52 \\
\hline 295.0 & 3563 & -1.06 & 1.24 & & & 225.0 & 3700 & 0.97 & 0.43 \\
\hline 305.0 & 3644 & -0.79 & 1.51 & & & 235.0 & 3800 & 1.28 & 0.33 \\
\hline 315.0 & 3726 & -1.13 & 1.52 & 2.11 & -0.98 & 245.0 & 3900 & 0.41 & 0.64 \\
\hline 325.0 & 3807 & -1.14 & 1.53 & 2.04 & -1.23 & 255.0 & 4000 & 1.24 & 0.80 \\
\hline 335.0 & 3889 & -1.29 & 1.50 & 1.45 & -1.14 & 265.0 & 4100 & 2.05 & 0.41 \\
\hline 345.0 & 3970 & -1.08 & 1.44 & 1.36 & -1.66 & 275.0 & 4200 & 1.55 & 0.49 \\
\hline 355.0 & 4064 & -1.13 & 1.47 & & & 285.0 & 4300 & 1.19 & 0.55 \\
\hline 365.0 & 4157 & -1.11 & 1.54 & 2.54 & -1.02 & 295.0 & 4544 & 0.52 & 0.22 \\
\hline 375.0 & 4251 & -0.74 & 1.62 & 2.73 & -0.92 & 310.0 & 4910 & 0.37 & 0.42 \\
\hline 385.0 & 4344 & -1.00 & 1.25 & & & 330.0 & 5400 & 1.75 & -0.49 \\
\hline 395.0 & 4438 & -0.63 & 1.36 & & & 356.0 & 6030 & 2.39 & -0.37 \\
\hline 405.0 & 4531 & & & 2.50 & -0.99 & 375.0 & 6500 & 1.91 & -0.71 \\
\hline 415.0 & 4625 & -0.81 & 1.12 & & & & & & \\
\hline 425.0 & 4718 & -0.90 & 1.20 & & & & & & \\
\hline 435.0 & 4812 & -0.83 & 1.28 & & & & & & \\
\hline 445.0 & 4905 & -1.13 & 1.42 & & & & & & \\
\hline 455.0 & 4999 & -1.17 & 1.52 & 1.69 & -1.57 & & & & \\
\hline 465.0 & 5092 & -1.09 & 1.53 & & & & & & \\
\hline 475.0 & 5186 & -1.09 & 1.49 & 1.50 & -1.26 & & & & \\
\hline 485.0 & 5279 & -1.20 & 1.31 & & & & & & \\
\hline 495.0 & 5373 & -1.22 & 1.39 & & & & & & \\
\hline 505.0 & 5466 & -0.94 & 1.17 & & & & & & \\
\hline 515.0 & 5560 & -0.90 & 1.13 & 1.62 & -1.55 & & & & \\
\hline 522.5 & 5630 & -0.91 & 1.07 & & & & & & \\
\hline
\end{tabular}

